\title{
APPLICATION OF "POLYSWITCH" FUSES FOR THE LIMITATION OF CURRENT OVERLOADS IN PHOTOVOLTAIC SYSTEMS OF SOLAR ARRAYS
}

\author{
A. V. Ivanchenko , A. S. Tonkoshkur, S. V. Mazurik \\ Oles Honchar Dnipro National University, Dnipro, Ukraine \\ *e-mail: IvanchenkoAV@ukr.net
}

\begin{abstract}
The results of experimental study of the transformation of the light current-voltage and volt-watt characteristics for the parallel connections of photovoltaic modules when using "PolySwitch" polymer resettable fuses are given. The conditions for selecting such fuses which allow their correctly triggering and minimize the current overload are formulated and experimentally verified. It is established that if resettable fuses are connected in series to the circuits of all photovoltaic modules, which are connected in parallel thus forming a unit, this prevents such a situation as the complete loss of electrical energy generated by this unit due to the short circuit of one of its modules. At the fuse triggering the total power loss of the unit of parallelly connected photovoltaic modules is mainly determined by the decrease of its current by the amount that is equal to the current of the disconnected photovoltaic module.

Keywords: solar array, current overload, resettable fuse, photovoltaic cell, current-voltage characteristics, power curve.
\end{abstract}

Received 03.09.2018; Received in revised form 14.10.2018; Accepted 21.11.2018

\section{Introduction}

Current overloads are related to failures, which to the greatest extent lead to the degradation of photovoltaic systems (PVS) of solar arrays and sometimes to abnormal (fire hazardous) situations. In particular, they cause local overheating of the functional and structural elements of PVS due to short circuits directly in the PVS and between the connecting terminals of the PVS [1-4]. Damages of the constituent elements of PVS by corrosion during their exploitation, "hidden" manufacturing defects, faulty blocking and bypass diodes, the results of insulation degradation under the environment action [2] and shunts formation due to reverse bias of photovoltaic cells caused by shading of modules or separate photovoltaic converters of the solar array during its exploitation [1] can be the physical causes of such situations.

In parallel connections of photovoltaic modules (PVM) the short circuit of one PVM leads to the loss of the entire generating unit and the decrease of the generated power by the total solar array power.

The most necessary condition for the wider use of parallel connections at the formation of modules and solar arrays is to eliminate or minimize the influences of said factor on the operation of solar arrays.

At present, considerable attention is paid to the development of methods and means for preventing electrical overloads. This overloads lead to the failures and the appearance of local overheating ("hot spot") in the photovoltaic components of solar arrays. In particular, such solutions of this problem are known: the use of photovoltaic converters (PVC) with a low reverse-breakdown voltage [5]; the inclusion of additional elements (in particular, bypass diodes and active bypass switches [3, 4, 6-8]) into the photovoltaic system; the methods and technical means based on the detection of a "hot spot" by measuring the electrical parameters of solar panels in combination with active protection by using the open circuit method [9, 10]. However, they are not universal. The use of PVC with a low reverse-breakdown voltage limits the power dissipated during heating of its local areas. However, such PVC can be the effective means to prevent a "hot spot" only if the amount of dissipated power is insufficient to damage the PVC [5]. The currently available simulation results and experimental data indicate that the bypass diodes in the subpanel lines of PVC do not fully protect against 
the appearance of "hot spots" [6-8]. Bypass diodes are more effective for preventing "hot spots" at very short PVC line lengths that is not used in modern panel design for economic reasons [5]. Active bypass switches, as well as technical means based on the detection of "hot spots", as well as complex automated systems for detecting "hot spots" are an improvement over the bypass diode, but they require more complex circuit solutions and expenses $[5,6,9,10]$.

The use of less expensive elements of functional electronics to isolate inactive (shaded or faulty) areas of both individual photovoltaic converters and their modules is one of the promising directions for solving the problem under consideration. In particular, it is proposed to isolate such areas through applying relatively new and widely used "PolySwitch" resettable fuses (RF) [3,11]. These elements of electrical and thermal protection have already found application in batteries and galvanic power sources [12-15]. The main advantages of the RF in comparison with traditional fuses are microminiature sizes and multiple switching (the RF do not lose operability after switching and do not require replacement) [12, 13].

Experimental testing of the functioning of circuit solutions for photovoltaic components using the indicated resettable fuses in real conditions is a necessary step in the development of this direction of increasing the reliability of solar arrays.

The study results for the transformation of light current-voltage and volt-watt characteristics of parallel connections of photovoltaic modules using "PolySwitch" resettable fuses to prevent and minimize current overloads are presented in this paper.

\section{Photovoltaic system with current limiting}

The model structure was used to study the capabilities of the "PolySwitch" resettable fuses experimentally for protecting against current overloads and short circuits in PVS of solar arrays. The model structure is a parallel connection of several series-connected photovoltaic modules and RF. The resistance box served as a load of such power source.

A short circuit of one photovoltaic module of such PVS in the absence of RF leads to the loss of the generated power of the entire parallel circuit containing other serviceable components.

The presence of resettable fuses connected in series with each photogenerating component makes it possible to preserve and operate the serviceable part of parallel circuit of the PVS in the presence of a short circuit in one of them.

Two conditions must be met at choosing an RF [11].

The first condition arises from the fact that the presence of such fuses in the electrical circuit should not affect the normal operation of the PVM:

$$
R_{\min }\left(\text { or } R_{1 \max }\right)<<R_{s}
$$

where $R_{\min }$ (or $R_{1 \max }$ ) - RF resistance in the conducting state (determined by passport values $R_{\min }-$ minimum device resistance at $23^{\circ} \mathrm{C}$ or $R_{1 \max }-$ maximum device resistance at $23^{\circ} \mathrm{C}, 1$ hour after tripping); $R_{s}$ - equivalent series resistance of module.

The second condition determines the tripping time of the RF. The tripping current of the RF $I_{\text {trip }}$ (minimum current through the RF, at which the transition from its conducting state to the non-conducting one occurs) must be greater than the short-circuit current of one (separate) PVM $I_{s c}$ and less than the operating current in the parallel connection of the photovoltaic modules in the operating mode $(n-1) I$ :

$$
(n-1) I>I_{\text {trip }}>I_{s c},
$$


The main measured characteristics were the current-voltage and volt-watt (power curve) characteristics of the model described above. The system consisting of three PVM was used in experiments. One of the modules was short-circuited to simulate a faulty module.

The special experimental automated measuring complex described in $[10,11]$ was used to register light current-voltage characteristics. The test bench allows using natural solar radiation as a source of light.

The PVM samples developed based on industrial silicon wafers SEF-4.5 [18] and PPTC type FRX375-60F [19] were used in experimental researches. The estimation of effective series resistance $R_{s}$ of the used PVM was conducted in accordance with the method [20,21]. The effective serial resistance was $\sim 1$ Oм. Passport values of parameters RF were $R_{\min }=0.03 \mathrm{Ohm}$ (or $R_{1 \max }=0.08 \mathrm{Ohm}$ ) and $I_{\text {trip }} \approx 3.5 \mathrm{~A}$ at a temperature of $\sim 50^{\circ} \mathrm{C}$, corresponding to the real operation mode of the PVS in the summer time.

\section{Experimental photovoltaic characteristics and their discussion}

The sequence of measurements was as follows. The dependences of the current $I_{L}$ of described photovoltaic system on the resistance value of the load resistor $R_{L}$ was measured. These dependencies corresponded to the situations (modes):

- without connecting resettable fuses (mode I);

- with fuses connected in series with each photovoltaic module (mode II);

- without fuses with one short-circuited module (mode III);

- with fuses connected in series with each photovoltaic module, one of modules is shortcircuited (mode IV).

The measurements of the dependence points of $I_{L}\left(R_{L}\right)$ corresponding to the indicated modes were almost simultaneous. It was achieved by using the appropriate switches.

The obtained experimental dependences of $I_{L}\left(R_{L}\right)$ are presented in Fig. 1.

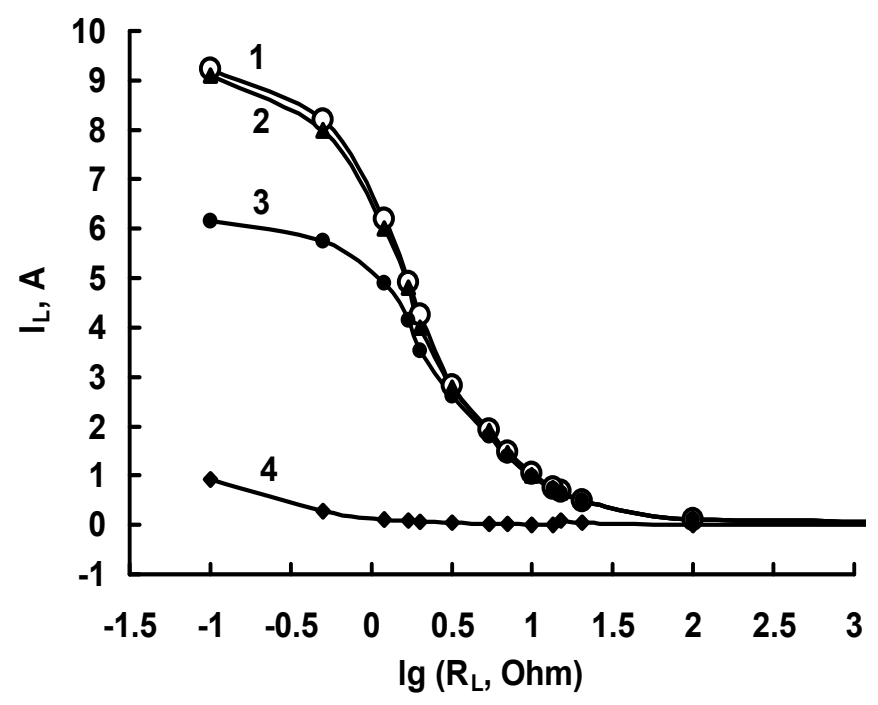

Fig. 1. Dependencies of the current in parallel connection of photovoltaic modules on the resistance value of the load resistor. Dependencies correspond to the modes: I - curve 1; II - 2; III - 4; IV - 3 . 
The current-voltage and volt-watt characteristics for modes I, II, IV are presented in Fig. 2. The characteristics for mode III is not shown on the Fig. 2 because they degenerate almost to the point $\left(I_{L}=0 ; U=0\right)$.
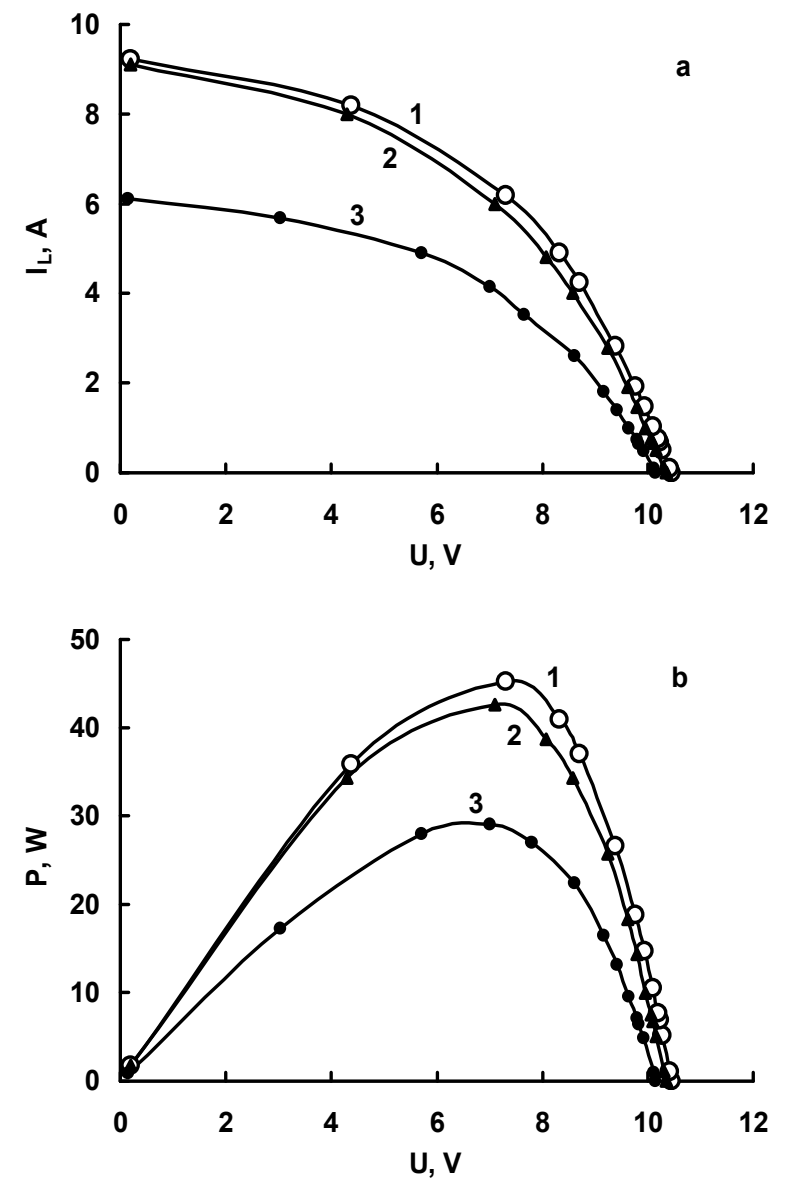

Fig. 2. Current-voltage (a) and volt-watt (b) characteristics in parallel connection of photovoltaic modules in modes I (curve 1), II (2), IV (3).

The dependences $I_{L}\left(R_{L}\right), I_{L}(U)$ and $P(U)$ measured in modes $\mathbf{I}$ and $\mathbf{I I}$ almost coincide. This indicates that condition (1) is fulfilled in this experiment. Thus, the inclusion of selected $\mathrm{RF}$ in series with each photovoltaic module practically does not affect the electrical properties of the considered PVS.

In the case of short-circuit of one of the PVM without RF connected in series with each module (mode III) the total load resistance of the PVS is the parallel connection of the resistance of the shorted PVM and the load resistance $R_{L}$. In the range of low resistances $R_{L}$ ( $R_{L}$ is comparable with the resistance of the short-circuited PVM) the total current of the PVS is divided into the components: the current of the load resistor and the current of the shortcircuited module. This is observed in Fig. 1. The transfer of the electrical energy to the load circuit is practically absent (PVS is inoperable) when the resistance $R_{L}$ exceeds the magnitude of the resistance of the short-circuited PVM. 
In the case of connected in series resettable fuses (mode IV) RF is triggered. When this occurs, there is only a slight decrease in the load current of PVS (Fig. 1 and $2 a$ ) caused by switching off the short-circuited PVM. In general, PVS can be considered operable, since it is capable of delivering electrical energy to the load, albeit smaller (Fig. $2 b$, curve 3).

\section{Conclusions}

It has been established that if the "PolySwitch" resettable fuses are connected in series to the circuit of each photovoltaic module at parallel connection of photovoltaic modules in a unit, then this prevents such the situation as the complete loss of electrical energy that is generated by this block due to the short circuit of one of its modules.

Using the fuse ensures the shutdown of the faulty (short-circuited) photovoltaic module through which an unacceptably high current passes. As a result, in this situation the total power loss of the block is determined by reducing its current by the value that equal to the sum of the current of one photovoltaic module and the small current maintaining the resettable fuse in the low-conducting state.

The conditions for the selection of such fuses which allow providing their correctly triggering and minimize the currents overload were formulated and experimentally verified.

\section{References}

1. Köntges, M. Review of failures of photovoltaic modules / M. Köntges, S. Kurtz, C. Packard, U. Jahn, K. A. Berger, K. Kato, T. Friesen, H. Liu, M. Van Iseghem // IEA PVPS Task 13. - 2014. $-132 \mathrm{p}$.

2. United Solar Technologies - Glavnaya / SMI i literatura / Osnovi solnechnoi energetiki / Solnechnie moduli i batarei. [Elektronnii resurs]. - Rezhim dostupa: http://ust.su/solar/media/section-inner17.

3. Tonkoshkur, A. S. Schemotechnical technologies for reliability of solar arrays / A. S. Tonkoshkur, L. V. Nakashidze, S. F. Lyagushyn // Systemni tehnologiï. Regionalny mizhvuzivsky zbirnyk naukovykh prats. - 2018. - Vip. 4'(117). - P. 95 - 107.

4. PV-magazine: Wenn Bypass-Dioden überhitzen [Elektronische Ressource]. - 2016. Modus zugriff: https://www.pv-magazine.de/2016/10/11/schwarze-schafe-wenn-bypassdioden-berhitzen/

5. Kim, K. A. Photovoltaic hot spot analysis for cells with various reverse-bias characteristics through electrical and thermal simulation / K. A. Kim, P. T. Krein // Proceed. of 2013 IEEE $14^{\text {th. }}$ Workshop on Control and Modeling for Power Electronics (COMPEL). USA, UT, Salt Lake City. - 2013. - P. $1-8$.

6. Kim, K.A. Reexamination of photovoltaic hot spotting to show inadequacy of the bypass diode / K. A. Kim, P. T. Krein // IEEE Journal of Photovoltaics. - 2015.- Vol. 5, No. 5.- P. $1435-1441$.

7. Acciari, G. Higher PV module efficiency by a novel CBS bypass [Text] / G. Acciari, D. Graci, A. La Scala // IEEE Transactions on Power Electronics. - 2011. - Vol. 26, No. 5. P. 1333 - 1336.

8. D'Alessandro, V. A simple bipolar transistor-based bypass approach for photovoltaic modules / V. D'Alessandro, P. Guerriero, S. Daliento // IEEE Journal of Photovoltaics. 2014. - Vol. 4, No. 1. - P. 405 - 413.

9. Sánchez Pacheco, F. J. Photovoltaic systems distributed monitoring for performance optimization / F. J. Sánchez Pacheco // Doctoral Thesis. - Universidad de Málaga. - 2015.

10. Di Napoli, F. Single panel voltage zeroing system for safe access on PV plants / F. Di Napoli, G. Guerriero, V. d'Alessandro, S. Daliento // IEEE Journal of Photovoltaics. 2015. - Vol. 5, No. 5. - P. 1428 - 1434. 
11. Tonkoshkur, A. S. Primenenie samovosstanavlivayuschihsya elementov dlya elektricheskoi zaschiti solnechnih batarei / A. S. Tonkoshkur, A. V. Ivanchenko, L. V. Nakashidze, S. V. Mazurik // Tekhnologiya i konstruirovanie v elektronnoy apparature. 2018. - N 1. - P. $43-49$.

12. Gavrikov, V. Samovosstanavlivayuschiesya PTC_predohraniteli dlya zaschiti ot tokovih peregruzok / V. Gavrikov // Novosti Elektroniki. - 2014. - N 12. - P. 11 - 15.

13. Kaminskaya, T. P. Samovosstanavlivayuschiesya predohraniteli dlya avtomobilnoi elektroniki / T. P. Kaminskaya, K. I. Domkin // Elektronnye komponenty. - 2008. - №5. - C. $80-82$.

14. Pat. 6608470 USA. Overcharge protection device and methods for lithium based rechargeable batteries / J. W. Oglesbee, A. G. Burns. - 19.08.03.

15. Protecting rechargeable $\mathrm{Li}$-ion and Li-polymer batteries [Electronic resource]: Littelfuse, Inc. - 2018.- Mode access: http://www.littelfuse.com/ /media/electronics/ application_notes/littelfuse_protecting_rechargeable_li_ion_and_li_polymer_batteries_in_co nsumer_portable_electronics_application_note.pdf.pdf

16. A.s. №1353995 SSSR, MKI F 24 O 2/38. Geliostat / N. I. Tyushkevich, V. M. Dubilovich, A. G. Kostyukovskii, G. E. Pilnikova. - zayavl. 18.06.86; opubl. 30.05.88. - Byul. № 20.

17. Degtyareva, N. A. Eksperimentalnoe issledovanie energeticheskih harakteristik solnechnih elementov razlichnih tipov pri estestvennom osveschenii / N. A. Degtyareva, G. I. Zarivnyak, S. A. Mitrohov, L. V. Nakashidze // Kosmichna nauka i tehnologiya. - 2004. - T. 10, № 1. - P. $16-19$.

18. Al-Oran, Bilal Fuad. Issledovanie i razrabotka kremnievih solnechnih elementov dlya fotoelektricheskih stancii i batarei nazemnogo primeneniya / Avtoref. dis. kand. tehn. nauk. - Institut energetiki i avtomatiki Akademii nauk Respubliki Uzbekistan. - 1995.

19. Fuzetec: FRX Series - Radial Leaded PTC: [Electronic resource]: Fuzetec Technology Co., LTD. - Mode access: http://www.fuzetec.com/products_2.php?bgid=1\&gid=31

20. Gremenok, V. F. Solnechnie elementi na osnove poluprovodnikovih materialov / V. F. Gremenok, M. S. Tivanov, V. B. Zalecskii. - Minsk: Izd. Centr BGU, 2007. - 222 p.

21. Migunov, Ya. N. Modelirovanie solnechnogo elementa $\mathrm{v}$ graficheskoi srede Simulink / Ya. N. Migunov // Molodejnii nauchno_tehnicheskii vestnik. Elektronnii jurnal. 2015. - № 7. - [Elektronnii resurs]: M.: MGTU im. N. E. Baumana. - Rejim dostupa: http://sntbul.bmstu.ru/doc/791154.html 